\title{
Preliminary evaluation of the suspending properties of Brachystegia eurycoma gum on metronidazole suspension
}

\author{
${ }^{*}$ Michael U Uhumwangho', Ikechukwu Louis Ileje ${ }^{2}$ \\ ${ }^{1}$ Department of Pharmaceutics and Pharmaceutical Technology, Faculty of Pharmacy, University of Benin, Benin City, Edo State, Nigeria \\ ${ }^{2}$ Department of Pharmaceutical Technology and Industrial Pharmacy, Faculty of Pharmacy, Madonna University, Rivers State, Nigeria
}

\begin{abstract}
The aim of this study was to evaluate the suspending properties of Brachystegia eurycoma gum on metronidazole suspension. The suspending properties of Brachystegia eurycoma gum (family leguminosae) were evaluated comparatively with that of compound tragacanth powder at concentration range of $2.5-10.0 \% \mathrm{w} / \mathrm{v}$ in metronidazole suspension. The following parameters were determined; sedimentation volume (\%), viscosity, $\mathrm{pH}$ and re-dispersion number. The values obtained were used as basis for comparison of the suspending agents studied. Brachystegia eurycoma and compound tragacanth gums had a $\mathrm{pH}$ range between 4.7 to 4.9 and between 3.9 to 4.1 respectively which indicates that they are slightly acidic. Particles suspended with tragacanth gum at concentration $\leq 7.5 \% \mathrm{w} / \mathrm{w}$ redispersed easily than those formulated with the Brachystegia eurycoma gum at $\leq 10 \% \mathrm{w} / \mathrm{w}$. It was observed that with increase in concentration of the gum the viscosity of the suspension increased correspondingly. For instance, at concentration of $2.5 \% \mathrm{w} / \mathrm{w}$ viscosities of the suspensions are 490 poise (Brachystegia eurycoma gum) and 603 poise (compound tragacanth gum) while at concentrations of $7.5 \% \mathrm{w} / \mathrm{w}$ their viscosities were 914 poise (Brachystegia eurycoma gum) and 1709 poise (compound tragacanth gum). There was a direct proportionality between viscosity of the gums at different concentrations and the sedimentation rate of the suspensions, as the viscosity of the gum increases, the rate of sedimentation of the suspension decreases. Brachystegia eurycoma gum at predetermined concentration can be exploited as an alternative excipient in the formulation of pharmaceutical suspensions of insoluble substances.
\end{abstract}

Key Words: Brachystegia eurycoma gum, suspending agents, viscosity, sedimentation volume, redispersed.

\section{INTRODUCTION}

Suspending agents are agents that help to decrease the sedimentation rate of particles in suspension. It achieves its function by increasing the viscosity of the liquid vehicle, thereby reducing settling in accordance with Stokes Law. These agents are classified as natural polysaccharides, semi-synthetic or synthetic (Martin et al., 1991; Banker and Rhodes, 1998; Malviya et al., 2011). Gums and mucilage are mainly used to enhance suspension of insoluble substances in liquid formulations. Their viscous and colloidal features help avert instant sedimentation. They may also function as binders in tablet formulations, as gelling agents, stabilizers or emulsifiers in preparation of emulsions.

Brachystegia eurycoma Harms (synonym B. spiceaformis) family leguminosae is a plant found frequently in the forest zone in southern Nigeria and Cameroun. The seeds are excellent source of bioactive compounds. It consists mainly of alkaloids, saponins, flavonoids, phenolic compounds, tannins, protein, carbohydrate, lipids and fiber. It is also an excellent source of water soluble vitamins therefore it plays a key function in the nutritional status of consumers (Uhegbu et al., 2009). It is usually called Achi by the Igbos, Akalado or Eku by Yorubas, Akpakpa or Apaupan by the Ijaw and Okwen by the Edos (Ikegwu et al., 2010). The seed is utilized as a soup spice and thickening agent in south eastern Nigeria. Brachystegia eurycoma seed gel when combined with snail mucin and honey, this has been explored for the treatment
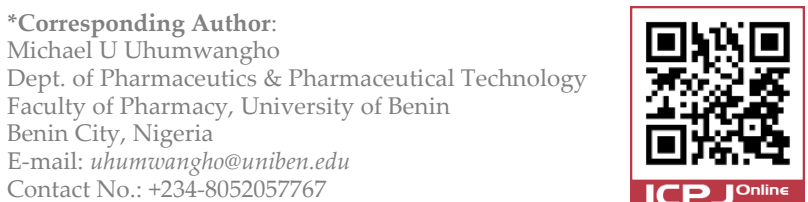

of wounds (Adikwu and Enebeke, 2007). Recently, Brachystegia eurycoma gum was investigated in ameliorating brittle fracture during tableting when used as binders in tableting (Osazuwa and Uhumwangho, 2013).

Metronidazole is white to pale yellow, crystal or crystalline powder; it is odorless with a slightly bitter taste and slightly saline. Its chemical named is $1 \mathrm{H}$-imidazole 1- ethanol, Methy-S-Nitro with a melting point of between $159^{\circ}$ and $163^{\circ} \mathrm{C}$. It is used in the treatment of Trichomoniasis, Ameobiasis and in the prophylaxis and treatment of anaerobic infection. The aim of the study was to investigate the suitability of Brachystegia eurycoma mucilage gum as a suspending agent in metronidazole suspension compared with compound tragacanth powder.

\section{MATERIALS AND METHODS}

The materials used include fine powder of metronidazole (Baif Laboratories Limited, Pune, India), benzoic acid BP, and amaranth solution (Merck, Germany), compound tragacanth powder (Searle Co. England), chloroform water double strength (BDH Chemical Ltd., England), and raspberry syrup BP (Best Ltd., England). Brachystegia eurycoma gum was extracted from undehulled seed of Brachystegia eurycoma by method described previously by (Olubunmi and Oremeyi, 2011) with some modifications.

\section{Formulation of suspensions}

Brachystegia eurycoma or compound tragacanth powder $(2.5 \mathrm{~g})$ and $10 \mathrm{~g}$ of metronidazole were triturated together with $30 \mathrm{ml}$ of chloroform water double strength to form a smooth paste. Amaranth solution $(1 \mathrm{ml})$ and $1 \mathrm{ml}$ of benzoic acid solution were incorporated steadily with constant stirring and then mixed with $20 \mathrm{ml}$ of raspberry syrup. The mixture was transferred into a $100 \mathrm{ml}$ amber bottle, made up to volume with distilled water and then shaken vigorously for 2 min (hence making $2.5 \% \mathrm{w} / \mathrm{v}$ of 
Table 1: $\mathrm{pH}$ and redispersibility number of prepared suspension using Brachystegia eurycoma or tragacanth gum.

\begin{tabular}{cccc}
\hline Suspending agent & $\begin{array}{c}\text { Conc. } \\
\text { (\%ow/v) }\end{array}$ & $\mathbf{p H}$ & $\begin{array}{c}\text { Redispersibility } \\
\text { number }\end{array}$ \\
\hline \multirow{3}{*}{ Brachystegia gum } & 2.5 & 4.7 & 7 \\
& 5.0 & 4.8 & 11 \\
& 7.5 & 4.9 & 13 \\
Tragacanth (\%) & 10.0 & 4.7 & 15 \\
\hline & 2.5 & 4.1 & 2 \\
& 5.0 & 3.9 & 4 \\
& 10.5 & 4.0 & 9 \\
\hline
\end{tabular}

the gum in the preparation). The procedure was repeated using 5.0, 7.5 and $10.0 \mathrm{~g}$ of Brachystegia eurycoma gum or compound tragacanth powder. The measuring cylinders were stoppered and placed on a vibration- free surface and stored at $28-30^{\circ} \mathrm{C}$.

\section{Determination of the suspension properties pH of suspension}

This was done using the $\mathrm{pH}$ meter. The respective suspensions at different concentrations were prepared and the $\mathrm{pH}$ of each was measured with the sensitive bulb of the $\mathrm{pH}$ meter. This was done 3 times for each suspensions and an average was taken and recorded. (Martin and Swarbrick, 2011).

\section{Sedimentation volume}

Formulated suspensions $(50 \mathrm{ml})$ were kept in a $50 \mathrm{ml}-$ measuring cylinder for duration of 7 days at $35 \pm 2{ }^{\circ} \mathrm{C}$. These suspensions were monitored hourly over a period of $7 \mathrm{hr}$ and subsequently daily for 1 week. The sedimentation volume, SV $(\%)$, was then determined the equation (Bankers and Rhodes, 1998)-

$\mathrm{SV}=100 \mathrm{~V}_{\mathrm{F}} / \mathrm{Vo}_{\text {, }}$

where $V_{F}$ is the final volume of the sediment and $V_{O}$ is the original volume of the suspension.

\section{Re-dispersion number}

After recording the sedimentation volume for one week the suspensions were redispersed and the re-dispersibility number for each of them were determined. This was done by inverting the cylinders and observing the number of times the cylinders were inverted until the bottom of the cylinder became free of particles.

\section{Rheological assessment}

Viscosities of the prepared suspensions (50ml) were determined at room temperature using the Brookfield Synchro-lectric viscometer, model number NDJ-5S

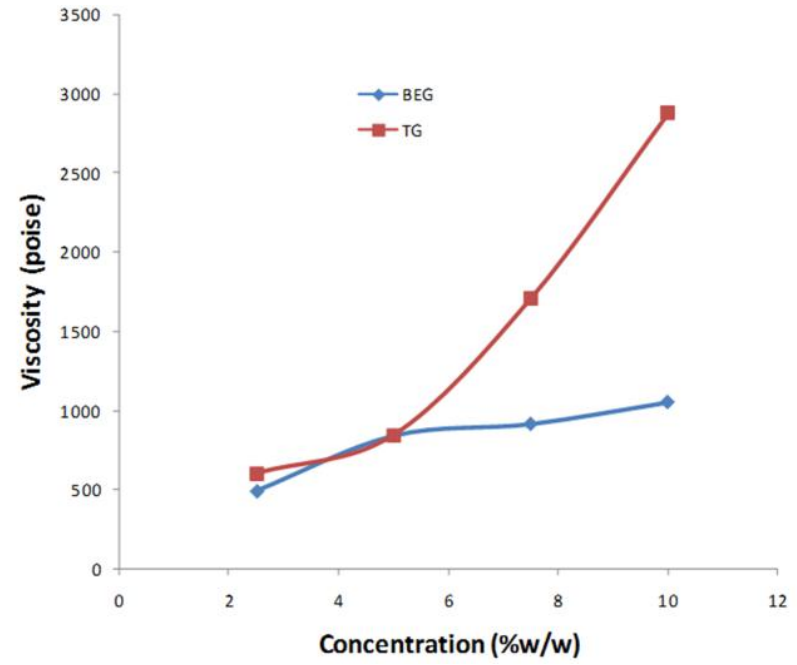

Figure 1: Effect of type and concentration $(2.5,5.0,7.5$ and $10 \% \mathrm{w} / \mathrm{w})$ on the viscosity of metronidazole suspension using BEG (Brachystegia eurycoma gum) and TG (Tragacanth gum).

(Brookfield Laboratories, Massachusetts). The guard leg and spindle were inserted into the suspension fluid and the viscometer was sheared at a speed of 50 revolutions per min (spindle number 3 ). The viscosity (in poise) of the different suspension was determined in quadruplicate and the mean values were calculated.

\section{RESULTS AND DISCUSSION}

\section{$\mathrm{pH}$ and redispersibility number}

The results of the $\mathrm{pH}$ are presented in table 1 . It was observed that Brachystegia eurycoma gum had a $\mathrm{pH}$ range between 4.7 to 4.9 which is slightly acidic while that of compound tragacanth gum had similar $\mathrm{pH}$ range i.e., between 3.9 to 4.1 . Redispersibility test which is an indication of how easy it is to redisperse a suspension after left to stand for one week. The result is presented in table 1. It was observed that particles suspended with tragacanth gum at $2.5,5$ and $7.5 \% \mathrm{w} / \mathrm{w}$ redispersed easily than those formulated with the Brachystegia eurycoma gum at $5 \%, 7.5 \%$ and $10 \% \mathrm{w} / \mathrm{w}$. However, suspensions prepared at $2.5 \% \mathrm{w} / \mathrm{w}$ using Brachystegia eurycoma gum was easily redispersed.

\section{Sedimentation volume}

Sedimentation volume i.e., ratio of the equilibrium volume of the sediment to the total volume of the suspension, was used to assess the suspensions prepared using varying concentrations of Brachystegia eurycoma or

Table 2: Sedimentation volume (\%) of metronidazole suspensions using different types and concentration of suspending agents.

\begin{tabular}{|c|c|c|c|c|c|c|c|c|c|c|c|c|c|c|c|}
\hline \multirow{3}{*}{$\begin{array}{l}\text { Suspending } \\
\text { agents }\end{array}$} & \multirow{3}{*}{$\begin{array}{l}\text { Conc } \% \\
\text { w/v }\end{array}$} & \multicolumn{14}{|c|}{ Sedimentation volume (\%) } \\
\hline & & \multicolumn{8}{|c|}{ Time (h) } & \multicolumn{6}{|c|}{ Time (days) } \\
\hline & & 0 & 1 & 2 & 3 & 4 & 5 & 6 & 7 & 1 & 2 & 3 & 4 & 5 & 6 \\
\hline \multirow{4}{*}{$\begin{array}{l}\text { Brachystegia } \\
\text { eurycoma gum }\end{array}$} & 0 & 100 & 19 & 15 & 15 & 15 & 15 & 15 & 14 & 14 & 14 & 14 & 14 & 14 & 14 \\
\hline & 2.5 & 100 & 22 & 16 & 16 & 16 & 16 & 16 & 15 & 15 & 5 & 15 & 15 & 15 & 15 \\
\hline & 5 & 100 & 92 & 90 & 81 & 81 & 65 & 65 & 62 & 60 & 60 & 60 & 60 & 60 & 60 \\
\hline & 7.5 & 100 & 96 & 96 & 94 & 94 & 88 & 82 & 78 & 76 & 74 & 72 & 72 & 72 & 72 \\
\hline \multirow{5}{*}{$\begin{array}{l}\text { Compound } \\
\text { tragacanth powder }\end{array}$} & 10 & 100 & 98 & 98 & 97 & 96 & 96 & 90 & 90 & 88 & 85 & 81 & 78 & 78 & 78 \\
\hline & 2.5 & 100 & 42 & 36 & 36 & 34 & 34 & 30 & 30 & 30 & 27 & 27 & 27 & 27 & 26 \\
\hline & 5 & 100 & 96 & 96 & 94 & 94 & 92 & 80 & 78 & 78 & 78 & 78 & 76 & 76 & 74 \\
\hline & 7.5 & 100 & 97 & 97 & 97 & 97 & 96 & 96 & 95 & 95 & 92 & 90 & 88 & 86 & 86 \\
\hline & 10 & 100 & 100 & 98 & 98 & 98 & 98 & 98 & 98 & 98 & 97 & 97 & 98 & 98 & 98 \\
\hline
\end{tabular}


compound tragacanth powder at 2.5, 5, $7.5 \& 10 \% \mathrm{w} / \mathrm{w}$ and left to stand over a period of (one week). The results of the sedimentation rate experiments are presented in table 2. The suspension formulated with Brachystegia eurycoma 2.5, $5,7.5$ and $10 \% \mathrm{w} / \mathrm{w}$ were observed to have high sedimentation rate although it formed suspensions which had better aesthetic than those formulated with tragacanth gum. All the Brachystegia eurycoma gum suspensions were observed to be deflocculated. Compound tragacanth at $2.5 \% \mathrm{w} / \mathrm{w}$ formed deflocculated suspension while at $5 \%$ and $7 \% \mathrm{w} / \mathrm{w}$ concentration it formed flocculated suspension and caked at $10 \% \mathrm{w} / \mathrm{w}$ concentration.

\section{Viscosity}

The results of the viscosity of the formulated suspension with Brachystegia eurycoma or compound tragacanth are shown in Figure 1. It was observed that with increase in concentration of the gum the viscosity of the suspension increased correspondingly. Moreso, there was a direct proportionality between viscosity of the gums at different concentrations and the sedimentation rate of the suspensions, as the viscosity of the gum increases, the rate of sedimentation of the suspension decreases.

\section{CONCLUSION}

Brachystegia eurycoma gum at predetermined concentration can be exploited as an alternative excipient in the formulation of pharmaceutical suspensions of insoluble substances. The results obtained are almost comparable to compound tragacanth powder.

\section{REFERENCES}

Adikwu, M.U and Enebeke T.C. (2007). Evaluation of snail mucin dispersed in Brachystegia eurycoma gum gel as a wound healing agent. Animal research international, 4 (2): 685-697.

Banker, S.G. and Rhodes, C.T., (1998). In: Modern Pharmaceutics. (3 ${ }^{\text {rd }}$ Edition) Pgs. 305-318.

Ikegwu, O.J, Okechukwu P.E. and Ekumankana E.O. (2010). Physicochemical and pasting characteristics of flour and starch from Achi; Brachystegia eurycoma seed. Journal of food technology, 8(2): 58-66. [DOI]

Martin A., Swarbrick, J., and Cammarata, A., (1991) In: Physical Pharmacy, (3rd Edition) pgs. 465, 544-553.

Olubunmi O and Oremeyi J (2011). Preliminary Evaluation of Brachystegia eurycoma seed mucilage as tablet binder. Int. J of Pharm. Res. and Innov. Vol. 3: 1-6.

Osazuwa EQ and Uhumwangho MU (2013). Potential of Brachystegia eurycoma gum in ameliorating brittle fracture during tableting. Nig. J Sci and Envr 12 (1) 98-102.

Rishabha Malviya, Pranati Srivastava and G.T. Kulkarni (2011). Applications of Mucilages in Drug Delivery - A Review. Advances in Biological Research 5 (1): 01-07.

Uhegbu, F.Q, Onwuchekwa C.C, Iweala E.J. and Kanu I. (2009). Effect of processing methods on nutritive and antinutritive properties of seeds of Brachystegia eurycoma and Detarium microcarpum from Nigeria. Pakistan Journal of Nutrition, 8: 316-320. [DOI] 